Macintyre, R. M. 1973: Lower Tertiary geochronology of the North Atlantic continental margins. In Pidgeon, R. T. et al. (edit.) Geochronology-Isotope Geology of Scotland. ECOG 111, K1-K25.

Mitchell, J. G. 1972: Potassium-argon ages from the Cheviot Hills, Northern England. Geol. Mag. 109, 421-426.

Wager, L. R. \& Deer, W. A. 1938: A dyke swarm and crustal flexure in East Greenland. Geol. Mag. 75, $39-46$.

School of Physics,

The University,

Newcastle upon Tyne NE1 7RU,

U.K.

\title{
Computer supported geological photo-interpretation
}

\author{
Hans F. Jepsen and Keld S. Dueholm
}

\section{Introduction}

The research project supported by the Danish Natural and Technical Science Research Councils (SNF \& STF) and GGU aiming at evaluating the use of advanced photogrammetrical techniques in geological photo-interpretation (Dawes, 1977) has continued during the past year. Methods which combine geological photo-interpretation with photogrammetrical techniques have been described by Dueholm (1976) and Dueholm et al. (1977).

This report describes a procedure and an instrumentation which makes it possible to combine precise drawing of geological boundaries with computer supported interpretation. $300 \mathrm{~km}^{2}$ of south-eastern Washington Land, western North Greenland was selected as a test area. 10 vertical aerial photographs at a scale of about 1:50 000 cover the area.

During the summer 1976 one of the authors (HFJ, in Peel, 1977) spent two weeks in the test area and lithological sections were measured at several localities. The geology is characterised by sub-horizontal Cambro-Ordovician sandstones, dolomites and limestones disturbed by block faulting (fig. 50). The layering of the strata is very conspicuous on the aerial photographs and several marker horizons can be defined and measured in the stereomodels.

The Institute of Surveying and Photogrammetry, Technical University of Denmark (DTH) provided the photogrammetric instruments. A Planitop F-2 stereo plotter equipped with $x, y, z$ encoders connected via a digitising module to a desk calculator (HP 9815 A) was used. Coordinates are transferred from the instrument to the desk calculator either continuously or point by point by a foot pedal.

\section{Procedure}

On a geological boundary, which is assumed to be an even plane, at least three points are measured and stored in the desk calculator. The parameters of the plane are calculated and 
stored on magnetic tape. If more than three points are measured, the plane is calculated using a least-square adjustment. In this case standard errors on the parameters are displayed.

Within a couple of minutes it is possible in a single model to measure points and to calculate the corresponding plane. This enables the geologist to repeat the procedure several times until he has the best fitting plane.

When one or more geological horizons are defined and stored, they can be handled by small utility programs according to the operator's choice. Dip and strike, thickness of strata between two horizons, and vertical displacements along faults, etc. can be calculated. The calculator can determine and display continuously the $z$ value of a geological horizon as a function of the incoming $x$ and $y$ values. A sound device on the calculator indicates when the $z$ setting on the instrument is correct, thereby enabling the geologist to trace well-defined bedrock geological boundaries into poorly exposed or covered areas.

All calculations are performed in ground coordinates allowing for points defining one single plane to be measured in several non-adjoining models. Similarly, planes defined in one model can be used in other models.

\section{Results}

The sedimentary sequence in the test area is divided into four formations (fig. 50). Each of these formations has its own characteristic morphological and colour appearance, and at certain localities the three boundaries between them can be traced without difficulty. However, elsewhere they are covered by Quaternary deposits and are not visible on the photographs. Therefore, they are not suitable for defining the structure of the area.

Instead of the three boundaries, two marker horizons were selected both of which appear as well-defined, pale horizons on the black and white photographs. The lowermost horizon (47) is situated 35-50 m below the top of Kastrup Elv Formation and is visible in many localities in the southern half of the test area. The other horizon (51) is situated $80-100 \mathrm{~m}$ above the base of Cass Fjord Formation and is well defined in many places in the northern two-thirds of the area.

Field measurements show that the general dip in the area is towards the north-north-east. Measurements in the instrument showed that the fault blocks composing the area have their own local dips. The range of dip from block to block is from $0.1^{\circ}$ to $1.1^{\circ}$ and the direction of dip varies between NNW and ENE. The displacements along the faults vary from 0 to $80 \mathrm{~m}$ vertically, and because of the difference in dips and dip directions of the blocks the relative displacements change along the faults.

\section{Accuracy}

The accuracy of the measurements and calculations depends on the scale of the photograph, the photogrammetric orientation, the precision of the instrument, and the distribution of the points measured on the geological horizon. These considerations applied to the area indicate standard errors of less than $0.1^{\circ}$ on dip angles and approximately $3 \mathrm{~m}$ on altitude readings. 


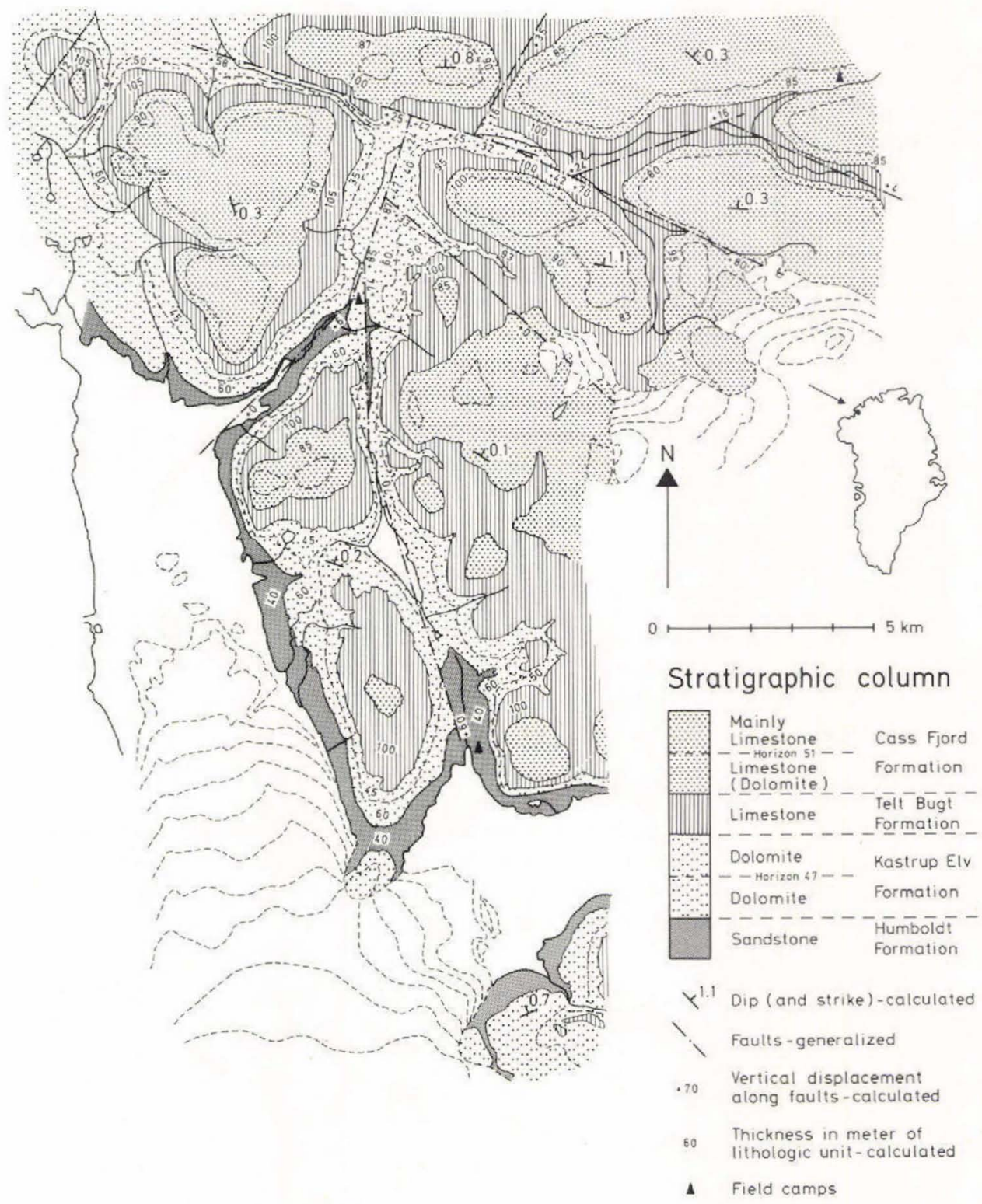

Fig. 50. Computer supported geological photo-interpretation of an area of Lower Palaeozoic strata in south-eastern Washington Land, western North Greenland. Quaternary cover is disregarded.

A factor which is difficult to evaluate is the precision by which one can determine and/or interpret the location of a geological boundary on the photographs. However, we are convinced that this factor is not so significant as to change the structures shown on the geological map (fig. 50). 


\section{Future developments}

Statistical programmes are being developed in order to increase the accuracy control especially on extrapolated horizons. Flexibility in defining the position of planar strata will be augmented thereby making it possible to calculate dip and strike in foliated basement areas without visible marker horizons.

Another topic to be examined during the coming year is the possibility of working in folded strata. Initially, programmes working with simple cylindrical and sinoidal surfaces will be developed to make it possible, to a certain extent, to calculate structural parameters in folded areas.

Registration of geological boundaries and structures possibly combined with registration of topographic features will be built up in the near future. It will then be possible to plot geological maps at any desired scale. In addition, it will be possible to combine automatically the drawing of geological and topographic maps (Dueholm, 1977).

\section{The Survey's instrumentation}

GGU purchased in 1977 a Kern PG-2 stereo plotter equipped with $x, y, z$ encoders. The encoders are connected to a digitising module which displays $x, y, z$ ground coordinates. The digitising module has a one-way connection to a desk calculator (HP $9825 \mathrm{~A}$ ), which will be used to calculate the various structural parameters. The desk calculator is interfaced to a motor drive on the $z$ column of the PG-2, enabling an automatic control of the $z$ setting according to pre-defined geological surfaces.

The registered data via cable connection will be stored on magnetic tape in GGU's minicomputer centre, and plotting will be carried out on GGU's Calcomp drum plotter.

Parts of this equipment will be installed and functional by the end of 1977; the complete instrumentation is expected to be in full operation by 1978 .

\section{Conclusions}

Combining (directly) a stereoscopic plotter and a desk calculator facilitates geological photo-interpretation and makes it possible with high precision and high speed to calculate structural parameters.

Dip and strike of planar strata, displacement and its variation along faults can be determined quickly. It is possible to extrapolate precisely the course of bedrock geological boundaries into poorly exposed and covered areas.

\section{References}

Dawes, P. R. 1977: Geological photo-interpretation of Hall Land: part of the regional topographic-geological mapping of northern Greenland. Rapp. Grønlands geol. Unders. 85, 25-30.

Dueholm, K. S. 1976: New instruments for geological photo-interpretation and mapping. Rapp. Grønlands geol. Unders. 80, 144-148.

Dueholm, K. S. 1977: Digital kortlægning. En mulig løsning. Medd. Inst. Landmål. Fotogramm. 9, 14 pp. 
Dueholm, K. S., Pedersen, A. K. \& Ulff-Møller, F. 1977: High precision photogrammetric methods used in geological mapping. Rapp. Grønlands geol. Unders. 81, 53-56.

Peel, J. S. 1977: Cambrian-Silurian studies in Washington Land, western North Greenland. Rapp. Grønlands geol. Unders. 85, 30-33.

K.S.D. Instituttet for Landmåling og Fotogrammetri, Danmarks Tekniske Højskole, Landmålervej 7 , 2800 Lyngby, Denmark.

\section{Establishment of an organic geochemical laboratory in GGU}

\section{J. Perregaard}

For some time organic geochemical evaluation of an appreciable number of surface samples from the Cretaceous-Tertiary sediments of West Greenland was performed by companies and research institutes outside Denmark (Schiener, 1976). In order to provide immediate control of the data produced, as well as to acquire the necessary expertise within Denmark, laboratory facilities for organic geochemical analysis were set up in GGU in the spring 1977 with financial support from the Danish Natural Science Research Council (SNF). Establishing these facilities is part of an energy research project initiated by SNF in late 1973 to evaluate fossil fuel potentials of sedimentary basins in Greenland.

A field sampling programme carried out in conjunction with 'Programmgruppe für Erdöl und Organische Geochemie' (EOG), Jülich, West Germany, (see Schiener \& Leythaeuser, this report) constituted another part of the project. The material collected is presently being investigated, with the aim of assessing the organic richness of the sediments, type of organic matter deposited, degree of thermal maturation and the influence of weathering and of intrusive igneous bodies upon the composition of the organic content.

Participation in evaluating results of petroleum exploration activities (Henderson, 1977) would be an obvious future task for a suitably equipped analytical laboratory with the experience obtained from onshore studies.

\section{Laboratory set-up}

The laboratory is equipped with instrumentation for solvent extraction of crushed sediments (soxhlett and ultrasonic) and for pre-separations of the extracts (column chromatography, urea adduction, molecular sieving etc.). To improve the quality and purity of commercially available solvents distillation is performed in packed columns with silvered vacuum jackets and packing material of high efficiency (stainless steel wire-mesh rings or Wilson helices). Further analysis of separate fractions is performed on a Hewlett-Packard 5840A gaschromatograph (fig. 51) controlled from a keyboard, which also functions as an integrator. Packed glass columns $(4 \mathrm{~m})$ with an eutectic salt mixture $\left(\mathrm{KNO}_{3}, \mathrm{NaNO}_{3}\right.$, 